\title{
Platin Grubu Metal İçeren Demir Matının Oksidatif Koşullarda Çözeltiye Alınmasının İncelenmesi
}

\author{
Mehmet Hakan MORCALI ${ }^{1,2 *}$, Merve AKSU ${ }^{2}$ \\ ${ }^{1}$ Gaziantep Üniversitesi, Naci Topçuoğlu Meslek Yüksekokulu, Kimya Teknolojisi, 27600, Gaziantep \\ ${ }^{2}$ Kahramanmaraş Sütçü İmam Üniversitesi, Avşar Kampüsü Mühendislik ve Mimarlık Fakültesi, Çevre \\ Mühendisliği, 46100, Kahramanmaraş \\ (ORCID: 0000-0002-5021-4459) (ORCID: 0000-0003-1212-8060)
}

\begin{abstract}
$\ddot{\mathbf{O} z}$
Özellikle kara taşıtlarında fosil bazlı yakıtların yakılması sonucu oluşan tehlikeli gazların $\left(\mathrm{CO}, \mathrm{NO}_{\mathrm{x}}\right.$, hidrokarbon (HC)) daha az zararlı gazlara $\left(\mathrm{CO}_{2}, \mathrm{~N}_{2}, \mathrm{H}_{2} \mathrm{O}\right)$ dönüştürülmesinde katalitik dönüştürücüler kullanılmaktadır. $\mathrm{Bu}$ kimyasal dönüşüm platin grubu metaller (PGM) varlı̆ı̆ında çok kısa sürede yüksek verimle gerçekleşmektedir. Dünya'da PGM konusunda yaşanan arz-talep dengesizliği sebebiyle her türlü PGM ihtiva eden atıktan değerli metallerin geri kazanımı çok büyük önem arz etmektedir. Bu bilimsel çalışmada, katalitik dönüştürücülerden katıkatı ekstraksiyon yoluyla PGM'lerin bünyesinde zenginleştirildiği demir matının çözeltiye alınma şartlarının belirlenmesi amacıyla hidroklorik asit varlığında farklı oksidanlar $\left(\operatorname{ozon}\left(\mathrm{O}_{3}\right)\right.$ ve oksijen $\left(\mathrm{O}_{2}\right)$ ) kullanarak çözümlendirme şartları araştırılmışıı. En iyi deney şartlarının belirlenmesi için oksidan türü, oksidan miktarı, çözücü konsantrasyonu, karıştırma hızı ve reaksiyon sıcaklı̆g parametreleri incelenerek deneyler

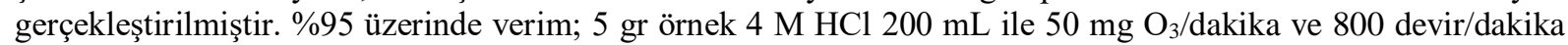
reaksiyon şartlarında 12 saat süre sonunda $60^{\circ} \mathrm{C}$ reaksiyon sıcaklığında elde edilebilmiştir. Deneylerin gerçekleştirildiği basamaklarda hammadde XRD analizi ile karakterize edilerek deneyde kullanılan hammaddenin yapısı aydınlatılmıştır. Çözünmeden geri kalan malzeme SEM-EDS yöntemi karakterize edilerek liç işlemi sonrası kalan yapı belirlenmiştir.
\end{abstract}

Anahtar kelimeler: Demir matı, çözümlendirme, oksidasyon, PGM.

\section{Investigation of Iron Matte Containing PGMs Leaching under Oxidative Conditions}

\begin{abstract}
Catalytic converters are especially used to convert hazardous gases $\left(\mathrm{CO}, \mathrm{NO}_{\mathrm{x}}\right.$, hydrocarbon (HC)) to less harmful gases $\left(\mathrm{CO}_{2}, \mathrm{~N}_{2}, \mathrm{H}_{2} \mathrm{O}\right)$ resulting from the combustion of fossil based fuels used in vehicles. The high yield of these reactions are achieved in a very short period of time by the platinum group metals (PGM) These chemical transformations take place in a very short time as well as with high efficiency in the presence of platinum group metals (PGM). Recycling of precious metals from all kind waste containing PGM is very important because of the supply-demand unbalance. In this scientific study, the dissolution conditions of iron matte which was produced by applying solid-solid extraction of PGMs from catalytic converters, were investigated in the presence of hydrochloric acid with using various oxidants (ozone $\left(\mathrm{O}_{3}\right)$ and oxygen $\left(\mathrm{O}_{2}\right)$ ). To determine the highest dissolution conditions, experimental studies were carried out by examining the oxidant type, oxidant quantity, solvent concentration, stirring speed and reaction temperature. At $95 \%$ dissolution yield was obtained using $5 \mathrm{~g}$ sample $200 \mathrm{~mL}$ of $4 \mathrm{M} \mathrm{HCl}$ with $50 \mathrm{mg} \mathrm{O} /$ minute and $800 \mathrm{rpm}$ at $60^{\circ} \mathrm{C}$ after $12 \mathrm{~h}$. The chemical composition of raw material was characterized by using XRD and also SEM-EDS technique was used to identify the undissolved material.
\end{abstract}

Keywords: Iron matte, dissolution, oxidation, PGM.

*Sorumlu yazar: hmorcali@ksu.edu.tr

Geliş Tarihi: 16.02.2020, Kabul Tarihi: 08.09.2020 


\section{Giriş}

Katalizör kimyasının temel taşlarından olan platin gurubu metaller (PGM) endüstrinin birçok alanında kullanılmaktadır. Sahip oldukları eşsiz özelliklerinin yanı sıra ekonomik değerleri PGM'lerin geri kazanılması konusunda yapılacak her türlü çalışmayı değerli kılmaktadır. Değerli metaller grubunda yer alan PGM'lerin metal borsasında kolaylıkla işlem görebilmeleri nedeniyle birçok endüstriyel kuruluş PGM'lerin kazanımı üzerine ticari faaliyetlerde bulunmakta ve yenilikçi her uygulama yakından takip edilerek çeşitli uygulamalara adapte edilme yolları aranmaktadır. Günümüzde çevresel kaygıların giderek artmasının yanı sıra kaynak kısıtlılığından dolayı yaşanan ekonomik kaygılar katalitik dönüştürücülerin değerlendirilmesinde yeni yöntem arayışını güncel tutmaktadır [1,2]. Yeni nesil çevreci araçların çıkması ile birlikte klasikleşmiş katalitik dönüştürücülerde bir takım değişikliklere uğramıştır. Yeni nesil birçok katalitik dönüştürücü bünyesinde SiC esaslı, metal esaslı, polimer esaslı malzemeler içermektedir [3-5]. Bu değişikliklerin yanı sıra araçların yanma sistemlerindeki olumlu gelişmeler katalitik dönüştürücülerin bünyelerindeki PGM miktarlarında azalmaya sebebiyet vermektedir. Katalitik dönüştürücülerde yaşanan bu değişimler bu alanda yeni çalışmaların yapılmasına ciddi zemin hazırlamaktadır. PGM'lerin daha yüksek verimlerle kazanılması ve geri kazanım yöntemindeki şartların iyileştirilmesi (çevresel ve ekonomik bakımdan) yönünde yapılacak çalışmalar ciddi önem kazanmaktadır. Literatür çalışmalarında katalitik dönüştürücülerden PGM'lerin kazanılması konusunda hidrometalurjik yöntemler baskın olmasına rağmen ticarileşmiş ve tescillenmiş endüstriyel uygulamalarda sıklıkla pirometalurjik yöntemler tercih edilmektedir [1-4, 6].

Literatür çalışmalarına bakıldığında bitmiş (atık) katalitik dönüştürücülerden PGM'leri katı-katı ekstraksiyon yoluyla ayırmak için: sıklıkla bakır $(\mathrm{Cu})$ ve nikel $(\mathrm{Ni})$, nadiren kurşun $(\mathrm{Pb})$, ve yeni olarak demir $(\mathrm{Fe})$ tercih edilmektedir [6]. Bunlara ek olarak kalsiyum $(\mathrm{Ca})$, magnezyum $(\mathrm{Mg})$ ve çinko $(\mathrm{Zn})$ kullanılan çalışmalarda bulunmaktadır. Bunlara ek olarak mat oluşumunun kullanıldığ durumlarda ise bakır sülfür $(\mathrm{CuS})$, nikel sülfür $(\mathrm{NiS})$ veya $\mathrm{Cu}-\mathrm{Ni}$-S karışımlı matının teşekkülü sağlanmıştır [1]. Metalik bakır, ticari bir değere sahip olması (metal borsasında satılabilir), rafinasyonun diğer metallere göre daha kolay oluşundan dolayı PGM'lerin seramik esaslı katalitik dönüştürücülerin toplamasında genellikle kullanılmaktadır [7-9]. Bu işlemlerde bakır kaynağı olarak; metalik bakır $\left(\mathrm{Cu}^{\circ}\right)$, bakır (II) oksit $(\mathrm{CuO})$ veya bakır karbonat $\left(\mathrm{CuCO}_{3}\right)$ kullanılmakta ve ergitme işlemi elektrik ark firınında gerçekleştirilmektedir. Katalitik dönüştürücünün ana yapısını oluşturan seramik malzemenin ergimesi için cüruflaştırıcı olarak $\mathrm{SiO}_{2}$ (silika) ve $\mathrm{CaO}$ (sönmüş kireç), redüktan olarak kömür ve türevleri kullanılmaktadır [9,10]. Ivanovic ve ark. (2011) tarafindan Belgrad Üniversitesi Bor Maden ve Metalurji enstitüsü tarafından geliştirilen yöntemde pelet haline getirilmiş olan katalitik dönüştürücü karışımı doğrudan ergitilmiş metalik bakır içerisine dökülmekte ve PGM'lerin ergimiş metalik bakır içerisinde çözümlendirilmesi sağlanmaktadır [11]. Fırın içerisinden cüruf sürekli olarak dışarı alınmakta ve yeni malzeme firına şarj edilmektedir. Elde edilen bakır levha yaklaşık olarak \%1 PGM içermektedir. Daha sonra elektroliz yöntemi ile PGM anot çamuru olarak alınmakta ve rafineriye gönderilerek PGM metalleri üretilmektedir. Fornalczyk ve Saternus (2009) tarafindan geliştirilen yöntemde ise PGM'ler bakır içerisinde toplandıktan sonra bakır alaşımı oksijen üfleme yoluyla oksitlenerek $\left(\mathrm{CuO}_{\mathrm{x}}\right)$ tekrardan ergitme firınına hammadde olarak verilmektedir [12]. Oksidasyondan sonra elde edilen PGM konsantresi miktarı \%30 civarındadır. Bu yöntem ticari olarak Japonya'daki Nippon PGM Corporation firması tarafından uygulanmaktadır [12]. Bakır ile PGM'leri toplayan bir diğer önemli firma olan Umicore (Hoboken, Antwerp, Belçika) ise katalitik dönüştürücülere ek olarak baskılı devre kartlarını da (elektronik atıklar) bu şekilde değerlendirerek diğer potansiyel değerli ( $\mathrm{Au}, \mathrm{Ag}$ ) ve özel metalleri (Se, $\mathrm{Te}, \mathrm{Sb}, \mathrm{Sn} v \mathrm{vb})$ kazanabilmektedir [13]. Fakat bakır ile PGM'leri toplama yönteminde elde edilen toplayıcının asit ile çözümlendirilme (sülfürik asit) işlemi yüksek sıcaklık ve basınç altında olmaktadır. Yüksek yatırım maliyeti (bakırın borsa satış fiyatı), bakırın elektroliz yöntemi ile kazanımı işleminde yüksek elektrik tüketimi, elektroliz ünitesinde çıkan asit buharları insan sağlığı ve çevre için tehlike arz etmesi en önemli dezavantajlarındandır. Toplayıcı metalleri atık cep telefonu baskı devre kartlarının bünyesinde sağlayarak baskı devre bünyesinde bulunan bakır, kalay ve demir varlığında katalitik dönüştürücülerdeki PGM'lerin ekstraksiyonu ve baskı devre kartlarının bünyesinde bulunan altın ( $\mathrm{Au})$ ve gümüşün $(\mathrm{Ag})$ aynı yolla ekstraksiyonu çalışılmıştır [14,15]. Kim vd. (2004) gerçekleştirdiği çalışmada toz halindeki katalitik dönüştürücü ve küçük parçalara ayrılan baskı devre kartları(PCBprinted circuit board) $600^{\circ} \mathrm{C}$ 'de yakılmıştır. Yakılma işleminde kül edilmiş PCB karışımı içerisinde bulunan $\mathrm{CuO}, \mathrm{SnO}_{2}$ ve $\mathrm{FeO}$ metal oksitleri toplayıcı görevi görmektedir. Karışımı kireç $(\mathrm{CaO})$ ile 
karıştırılarak yaklaşık olarak $1400^{\circ} \mathrm{C}^{\prime}$ de bir saat süre ile ergitilmiş ve ergitme sonrası elde edilen metal alaşımı kral suyunda liç edilerek değerli metallerin geri kazanımları ICP sonuçlarına göre hesaplanmış ve \%90 civarında değerli metal kazanımı sağlanmıştır. Yöntemde PCB'lerin kül edilmesi sırasında açığa çıkan organik kirlilik ve $\mathrm{Cu}-\mathrm{Sn}-\mathrm{Fe}$ alaşımından PGM-Au-Ag metallerinin geri kazanımı için hiçbir çalışma yapılmamıştır. Ayrıca ergitme işlemi için gerekli sıcaklığın yüksekliği bir diğer dezavantajı olarak belirlenmiştir. Kim vd. (2013) yürüttüğü bu çalışmada ise 2004 yılında gerçekleştirdikleri çalışmadan farklı olarak PCB kartlarını kül etmeden doğrudan ergitme potasına eklemişlerdir. Bir önceki çalışma ile aynı sonuçlar elde edilmiştir. Fakat oluşan organik kirletici gazların bertarafi, metal alaşımından PGM-Au-Ag metallerinin ayrımı ve toplayıcı metallerin tekrardan kullanımına yönelik çalışmalar verilmemiştir. Keyworth (1982) metalik kurşun ile PGM toplama yöntemini tanımlamıştır [16]. Bu yöntem pirometalurjik olarak PGM ayrıştırmadaki (toplama) en eski yöntemlerin başında gelmektedir. 1980 ve öncelerinde ikinci el hurda kaynaklarının değerlendirilmesinde kolay uygulanması, düşük ergime sıcaklığına sahip olması, kurşunun basit yolla uzaklaştırılabilmesi (PGM konsantresi eldesi için) ve düşük yatırım maliyeti avantajları arasındadır. Fakat çalışanlar ve çevre koşulları için toksik kurşun oksit $(\mathrm{PbO})$ oluşumu ve en önemlisi rodyum $(\mathrm{Rh})$ geri kazanım verimlerinin $\% 70$ civarında kalması en önemli dezavantajları olarak belirlenmiştir [16,17]. Günümüzde bu yöntemin uygulanmasına yönelik çalışma bulunması yöntemin uygulanma potansiyelini yitirmiştir. Plazma ark ergitme teknolojisinin 1980'lerden sonra gelişmesi ile birlikte PGM'lerin toplanması için metalik demir sıklıkla tercih edilen metallerin başında gelmektedir $[6,18]$. Bu proseste kırılmış katalitik dönüştürücüler demir cevheri $\left(\mathrm{Fe}_{2} \mathrm{O}_{3}\right)$ veya metalik demir tozu ile karıştırılarak redükleyici ve cüruflaştırıcı varlığında yaklaşık olarak $2000^{\circ} \mathrm{C}$ 'de ergitilmesi sırasında PGM'ler metalik demir bünyesinde toplanmaktadır (işlem sonrası demir bünyesinde yaklaşı \%7 PGM içerir). Plazma ergitme sistemi ticari olarak ABD ve Çek Cumhuriyetinde kullanılmaktadır [19]. Kullanılan prosesin (plazma ark ergitme) bakım ve onarım maliyetlerinin çok yüksek oluşu ve kullanım ömrünün kısa oluşu en önemli dezavantajları olarak ortaya çıkmaktadır. Ayrıca çok yüksek enerji maliyeti sürdürülebilir çevre uygulamaları ile bağdaşmayan özelliklerinin başında gelmektedir. Katalitik dönüştürücülerden PGM'lerin metal buharları ile alaşımları şeklinde kazanımlarının sağlandığı bir takım çalışmalar mevcuttur fakat çalışmaların sürdürülebilirliği konusunda çalışmaların derinleştirilmesi gerektiği raporlarda belirtilmiştir. Katalitik dönüştürücülerdeki rodyumu $(\mathrm{Rh}) \mathrm{Ca}$ ve $\mathrm{Mg}$ metallerinin tozları ile özel olarak tasarlanmış kapalı reaktörde yaklaşık $900^{\circ} \mathrm{C}$ 'de oluşan $\mathrm{Ca}$ ve $\mathrm{Mg}$ metal buharları ile Rh'un alaşımlanması ve elde edilen alaşımın kral suyunda $\left(3 \mathrm{HCl}: \mathrm{HNO}_{3}\right)$ asidik olarak çözümlendirilmesi sağlanmıştır. Elde edilen çözeltiden rodyum metali sementasyon $(\mathrm{Zn})$ yöntemi ile indirgenmiş \%100 yakın verim elde edilmiştir [20]. Bir farklı çalışmasında katalitik dönüştürücülerin yapısında bulunan PGM'lerin Ca ve $\mathrm{Mg}$ metallerinin tozları ile özel olarak tasarlanmış kapalı reaktörde yaklaşık $900^{\circ} \mathrm{C}$ 'de 3 saat sonunda oluşan alaşımların kral suyunda $\left(3 \mathrm{HCl}: \mathrm{HNO}_{3}\right)$ asidik olarak çözümlendirilmesi sağlanmıştır. Elde edilen verim değerlerinin sırasıyla \%88 Pt, \%81 Pd, ve \%72 Rh olduğu belirtilmiştir [20]. Bir patent çalışmasında katalitik dönüştürücüde bulanan platin grubu metalleri sülfatlaştırıcı kavurma yoluyla çözeltiye almışlardır. Çalışmada, sadece çözümlendirme üzerine gerçekleştirilmiş platin grubu metallerin geri kazanımı hakkında bilgi verilmemiştir. Ayrıca reaksiyon sırasında açığa çıkan $\mathrm{SO}_{3}$ gazlarının bertarafı konusunda bilgi verilmemiştir [21]. Bakır ergitme sonrası elde edilen cüruf içerisinde kalan bakırın miktarının PGM konsantrasyonu ile ilgili yapılan başka bir patent çalışmasında bakır miktarı azaldıkça PGM miktarının da azaldığı tespit edilmiştir [22]. Literatürde NiS matı ile ilgili yapılan çalışmalarda genellikle standart referans cevherlerde (Kromit, manganez, pirit v.b.) bulunan platin grubu metallerin çeşitli spektroskopik yöntemle analizleri hakkındadır. Bu çalışmalarda genellikle spektroskopik teknikler karşılaştırılmış ve karşılaşılan sorunlar için alınması gereken önlemler araştırılmıştır $[23,24]$. NiS mat1 yönteminin katalitik dönüştürücüler kullanılarak reaksiyon şartlarının belirlenmesine yönelik gerçekleştirilen çalışmada \%99'a yakın PGM geri kazanım elde edilmiş fakat PGM'lerin çözeltiye alındıktan sonra selektif olarak çöktürülmesi, daha sonra çözeltideki nikelin tekrardan kazanılarak yöntemde kullanımı hakkında çalışmalar eksik kalmıştır [4].

Yukarıda detaylı olarak verilen literatür ve patent çalışmalarından anlaşıldığg üzere katalitik dönüştürücülerden PGM'leri geri kazanılması konusunda halihazırda endüstriyel uygulamaları bulunan pirometalurjik yöntemler ön plana çıkmaktadır. Metal ergitme ile toplama işlemi özellikle refrakter ve düşük PGM içerikli katalitik dönüştürücülerin değerlendirilmesi için en uygun geri kazanım yöntemi olduğu bir kaç derleme makalesinde belirtilmektedir [1,25]. Literatürde yayınlanan son çalışmalarda PGM'lerin çeşitli endüstriyel proseslerden elde edilen matlarda zenginleştirilmesi ve bu matların 
çözümlendirilme şartlarının belirlenmesi üzerine araştırmalar yapılmıştır. Örneğin; $\mathrm{Ni}-\mathrm{Cu}-\mathrm{Fe}-\mathrm{S}$ Peirce Smith konvertör matı; Ni-Cu konvertör matı; Ausmelt yöntemi konvertör matlarının çeşitli şartlarda farklı çözücüler varlığında çözümlendirilmesi incelenmiş ve PGM'lerin geri kazanımı üzerine bir dizi çalışmalar yürütülmüş̧ür [24-26]. Fakat bu çalışmalar genellikle sülfürlü cevherlerde var olan PGM'lerin geri kazanımı üzerine gerçekleştirilmiştir. $\mathrm{Bu}$ çalışmalara ek olarak diğer literatür çalışmalarında katalitik dönüştürücü kullanılmamıştır.

$\mathrm{Bu}$ çalışmada; PGM'lerin katalitik dönüştürücülerden katı-katı ekstraksiyon yoluyla demir matında zenginleştirilmesi sonrası elde edilen demir matının hidroklorik asit varlığında iki adet farklı oksidan ile çözümlendirilmesi üzerine etki eden parametreler incelenmiştir. Deneylerin gerçekleştirildiği basamaklarda hammadde XRD ve çözünmeden geri kalan malzeme SEM-EDS tekniği uygulanarak karakterize edilmiştir.

\section{Materyal ve Metot}

Çeşitli marka araçlara ait bitmiş katalitik dönüştürücülerden elde edilen paçal tozunun üç katı miktarda $\left(0,72\right.$ ağırlıkça $\left.\mathrm{B}_{2} \mathrm{O}_{3} / \mathrm{Na}_{2} \mathrm{O}\right)$ cüruflaştırıcı varlığında 10 gr pirit ile $950^{\circ} \mathrm{C}$ ve 75 dakika süreyle bir dizi deneyler yapılarak yaklaşık 200 gr demir matı üretilmiştir. Deneylerden elde edilen demir matı halkalı seramik ögütücüde kırılarak toz haline getirilmiştir (Bknz. Tablo 1).

Öğ̈̈tme işlemi $100 \mu \mathrm{m}$ (mikron) boyutun altında kalacak şekilde yürütülmüştür. Daha küçük boyutlu öğütme işleminde tozun aşırı 1sınmasından dolayı değirmene sıvanma çok fazla artmaktadır. Ayrıca aşırı 1sınmadan dolayı yapı içerisinde bulunan kükürt değirmende bulunan oksijen ile reaksiyon vermektedir. Bu sebeple deneysel çalışmalarda farklı tane boyutu incelemesi yapılmamıştır. Şartların imkan verdiği en uygun boyuta kadar öğütme işlemi gerçekleştirilmiştir. Ögütülen toz 100 mikron elekten geçirilerek elek üstünde kalanlar tekrardan öğütme işleminde kullanılmıştır. Son olarak öğütülmüş toz deneylerde kullanılmak üzere kilitli torbada muhafaza edilmiştir.
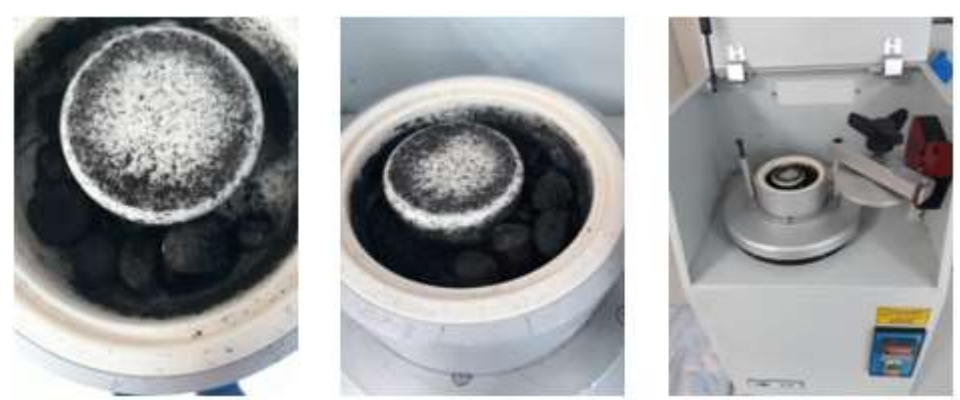

Şekil 1. Seramik halkalı değirmen ile öğütülen demir matları

Elde edilen toz üç boyutlu karıştırıcı ile homojenize edilmiştir. Daha sonra toz X-1şınları kırımı Şekil 2'de verilmiştir. X-ı̧sınları kırımına ait pikler pirit yapısını göstermektedir.

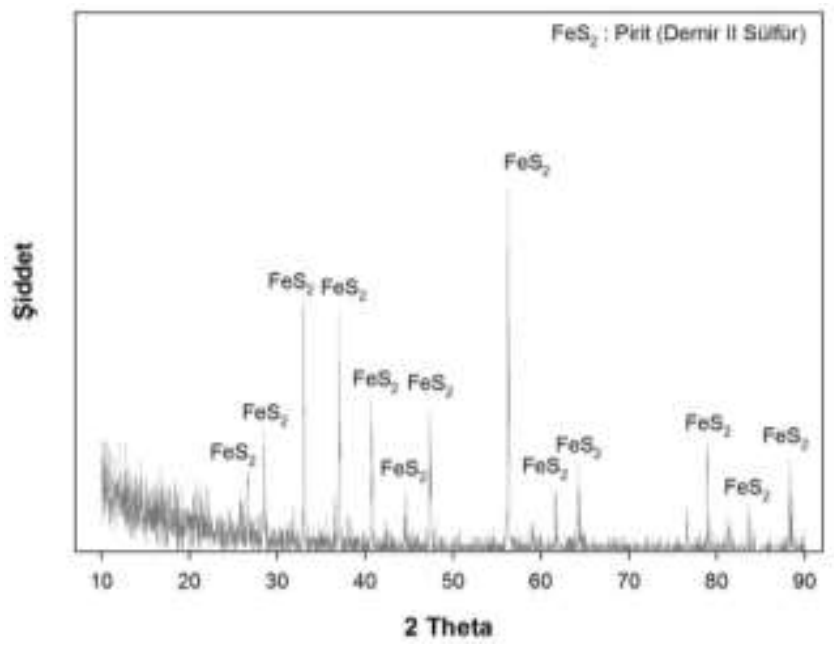

Şekil 2. Elde edilen demir matına ait XRD analizi. 
Matın kimyasal içeriğinin belirlenmesi için laboratuvar içi mikrodalga çözümlendirme yöntemi kullanılmıştır. Mat içerisinde var olan kükürdün oksidasyonu sonucu oluşan sülfat anyonları baryum klorür $\left(\mathrm{BaCl}_{2}\right)$ gravimetrik yöntemi ile tespit edilmiştir. Çözeltiye geçen demir iyon konsantrasyonu ise kompleksometrik (EDTA) titrasyon yöntemi ile 5-sülfosalisilik asit varlığında tespit edilmiştir. Bahsi geçen yöntemler hakkında daha detaylı bilgi literatürde mevcuttur [27]. Bu yöntemlere ek olarak AAS ve ICP-OES cihazları kullanılarak sonuçların güvenilirliği sağlanmıştır. Matın kimyasal içeriğine ait bilgiler Tablo 1'de belirtilmiştir.

Tablo 1. Elde edilen demir mat karışımına ait kimyasal bileşimi.

\begin{tabular}{cc}
\hline Elementler & Ă̆ırlıkça, (\%) \\
\hline $\mathrm{Fe}$ & 46,93 \\
$\mathrm{~S}$ & 44,71 \\
\hline Elementler & Ăğrlıkça, (mg/kg) \\
\hline $\mathrm{Pt}$ & 145 \\
$\mathrm{Pd}$ & 1017 \\
$\mathrm{Rh}$ & 141 \\
\hline
\end{tabular}

Çözümlendirme deneyleri kontak termometreli (sıcaklık kontrollü) geri soğutuculu reaktörlerde yapılmıştır. Çözümlendirme işlemi sırasında oksidanlar çözeltiye verilerek etkileri incelenmiştir. Matın çözünmesine ait verimler ve arta kalan PGM kalıntısı selüloz asetat esaslı $0,45 \mu \mathrm{m}$ gözenekli membran filtreden süzülerek ayrılmıştır.

\section{Bulgular ve Tartışma}

Deneysel çalışmalardan elde edilen bulgular verilmekte ve ilgili literatür ile karşılaştırılmaktadır.

\subsection{Oksidan türünün mat çözümlendirme verimi üzerine etkisi}

Oksidan türünün belirlenmesine yönelik gerçekleştirdiğimiz bu çalışmada örnek miktarı (5 gr mat tozu) ve çözücü miktarı $(200 \mathrm{~mL})$ tüm çalışmalarda sabit tutulmuştur. Ayrıca, asit konsantrasyonu $1 \mathrm{M}$ olarak belirlenerek oksidan türlerinin çözücü içerisindeki etkisi ve ek olarak oksidanların çözücü içerisindeki çözünürlügünü maksimum seviyede tutmak amaciyla reaksiyon oda sıcaklığında en azami sistem şartlarından yararlanarak 1440 dakika (24 saat) yürütülmüştür.

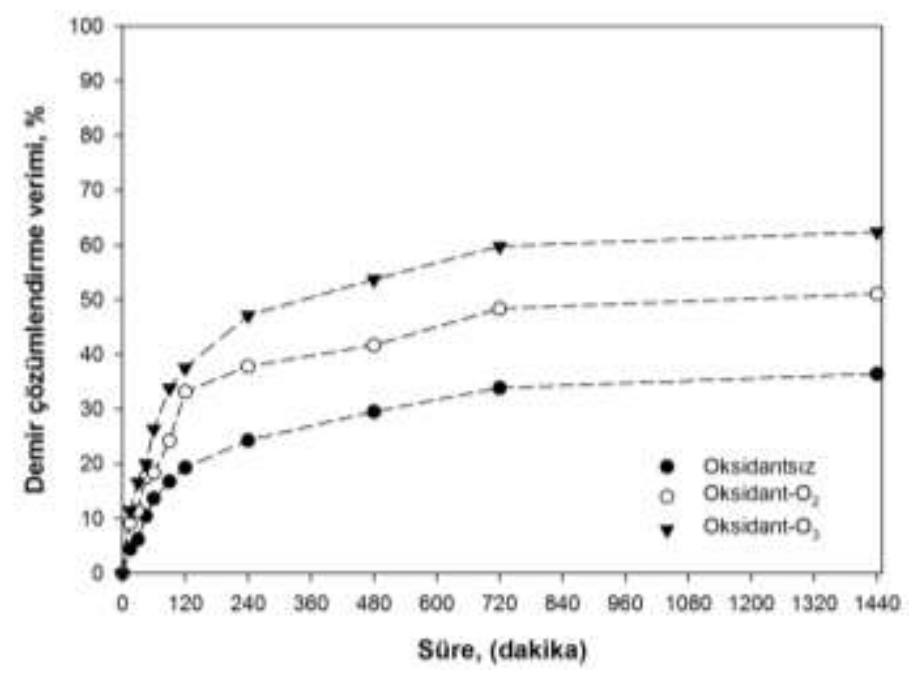

Şekil 3. Oksidan türünün mat çözümlendirme verimi üzerine etkisi (5 gr örnek, $1 \mathrm{M} \mathrm{HCl} 200 \mathrm{~mL}$, oda sıcaklığı, $50 \mathrm{mg}$ oksidan/dakika, 800 devir/dakika).

Grafikten görüleceği üzere oksidansız bir ortamda matın çözümlendirme veriminin çok düşük kaldığı anlaşılmaktadır. Bu sebeple güçlü oksidanlardan olan oksijen $\left(\mathrm{O}_{2} ; 1,23 \mathrm{~V} / \mathrm{SHE}\right)$ ve ozon $\left(\mathrm{O}_{3}\right.$; 2,07 V/SHE) kullanılmış ve en iyi verimin beklendiği üzere ozon ile elde edildiği Şekil 3'den anlaşılmaktadır. 


$$
\begin{array}{ll}
\mathrm{O}_{2}+4 \mathrm{H}^{+}+4 \mathrm{e}^{-}=2 \mathrm{H}_{2} \mathrm{O} & \mathrm{E}^{\circ}=1,23 \mathrm{~V} \\
\mathrm{O}_{3}+2 \mathrm{H}^{+}+2 \mathrm{e}^{-}=\mathrm{O}_{2}+\mathrm{H}_{2} \mathrm{O} & \mathrm{E}^{\circ}=2,07 \mathrm{~V}
\end{array}
$$

24 saat süren liç deneyleri sonucunda yaklaşık olarak matın \%65'nın çözündürülebileceği tespit edilmiştir. Buna rağmen oksijen kullanıldığ 24 saat deney süresinde $\% 50$ civarında verim elde edilebilmiştir. Çözünme veriminin düşük kalmasının ana sebebini açıklamak için pirit ile oksidanlar arasındaki reaksiyonları incelenmiştir. Genel olarak piritin oksijen ve ozon ile reaksiyonuna ilişkin denklemeler aşağıda verilmiştir.

$$
\begin{aligned}
& 4 \mathrm{FeS}_{2}+15 \mathrm{O}_{2}+2 \mathrm{H}_{2} \mathrm{O}=2 \mathrm{Fe}_{2}\left(\mathrm{SO}_{4}\right)_{3}+2 \mathrm{H}_{2} \mathrm{SO}_{4} \\
& 2 \mathrm{FeS}_{2}+5 \mathrm{O}_{3}+\mathrm{H}_{2} \mathrm{O}=\mathrm{Fe}_{2}\left(\mathrm{SO}_{4}\right)_{3}+\mathrm{H}_{2} \mathrm{SO}_{4}
\end{aligned}
$$

Denklemlerden görüleceği üzere oksijen ve ozon gibi oksidanlar varlığında demirin üç değerlikli olarak çözündüğü ve bu çözünme işlemi sırasında ortamda var olan kükürdün \%100'e yakın verimle oksitlenerek sülfürik asit oluşturması teorik olarak beklenmektedir. Realitede ise ozonun oksidan olarak kullanıldığı durumlarda reaksiyon ürünü olarak oksijenin çıktığı bilinmektedir.

$$
2 \mathrm{FeS}_{2}+15 \mathrm{O}_{3}+\mathrm{H}_{2} \mathrm{O}=\mathrm{Fe}_{2}\left(\mathrm{SO}_{4}\right)_{3}+\mathrm{H}_{2} \mathrm{SO}_{4}+15 \mathrm{O}_{2}
$$

5'nolu denklemde görüldügüü üzere teorik olarak 4'nolu denklemde gerekenden üç kat daha fazla ozona ihtiyaç duyulmaktadır. Bu durum göz önüne alındığında sistemde kullanılacak ozon miktarının çok aşırı olması gerekmektedir ki, bu durum prosesin sürdürülebilir olmasını engellemektedir. Ayrıca bu kadar çok miktarda ozon üretebilecek bir cihazının verimliliği ve kullanım ömrünün kısıtlı olması sürekli yatırım maliyetlerinin artmasına sebep olacaktır. Saymış olduğumuz dezavantajlardan ötürü sistemin verimliliğini oksidan miktarını sürekli sabit tutarak diğer reaksiyon parametrelerinin değiştirilmesi sonucu verimlilik değerleri üzerindeki etkileri incelenmiştir. Uyguladığımız liç işlemi için olası reaksiyonlar 6 ve 7'de verilmektedir [28].

$$
\begin{aligned}
& 8 \mathrm{FeS}_{2}+13 \mathrm{O}_{2}+12 \mathrm{HCl}=4 \mathrm{FeCl}_{3}+2 \mathrm{Fe}_{2}\left(\mathrm{SO}_{4}\right)_{3}+6 \mathrm{H}_{2} \mathrm{~S}+3 \mathrm{~S}+\mathrm{SO}_{2} \\
& 8 \mathrm{FeS}_{2}+11 \mathrm{O}_{3}+12 \mathrm{HCl}=4 \mathrm{FeCl}_{3}+2 \mathrm{Fe}_{2}\left(\mathrm{SO}_{4}\right)_{3}+6 \mathrm{H}_{2} \mathrm{~S}+4 \mathrm{SO}_{2}+1 / 2 \mathrm{O}_{2}
\end{aligned}
$$

Oksijen ile pirit arasındaki reaksiyon incelendiğinde ozonun kullanımı ile ortamda oluşabilecek elementel kükürt miktarı azalarak ortama bir miktar asit oluşturmaktadır. Bu durum sisteme katk1 sağlayabilecek bir durum gibi düşünülebilir fakat Le Chaliter prensibine ortamda artan sülfat anyonu konsantrasyonu reaksiyonu kinetik olarak yavaşlamasına veya sterik olarak engelleyebileceği düşünülebilir [29].

\subsection{Hidroklorik asit konsantrasyonun mat çözümlendirme verimi üzerine etkisi}

Çözümlendirme çalışmalarının yürütüldüğü bu deneysel çalışma grubunda farklı hidroklorik asit konsantrasyonlarında demirin çözeltiye geçme verimi incelenmiştir. Bir önceki deney grubunda oksidan olmadan çözümlendirmenin arzu edilen düzeylerde (yani; yüksek verimle) olmadığ 1 tespit edilmiştir (örneğin; 6 saat deney süresi sonunda \%30 civarında bir çözünme elde edilmiştir). Bir önceki oksidan türleri kullanılarak çözümlendirme verimlerine etki eden asit konsantrasyonun belirlenmesine yönelik sıralı deneyler gerçekleştirilmiştir. Deneyler sırasında örnek miktarı (5 gr demir matı tozu) ve çözücü miktarı $200 \mathrm{~mL}$ olacak şekilde sabit tutulmuştur. 0,5 ile $6 \mathrm{M}$ arasında farklı asit konsantrasyonları seçilerek oluşturulan görsel detaylı bilgi içermesi sağlanmıştır. Reaksiyon sıcaklığı olarak oda sıcaklığı seçilmiş verimler zamana karşı grafiğe işlenmiştir. 


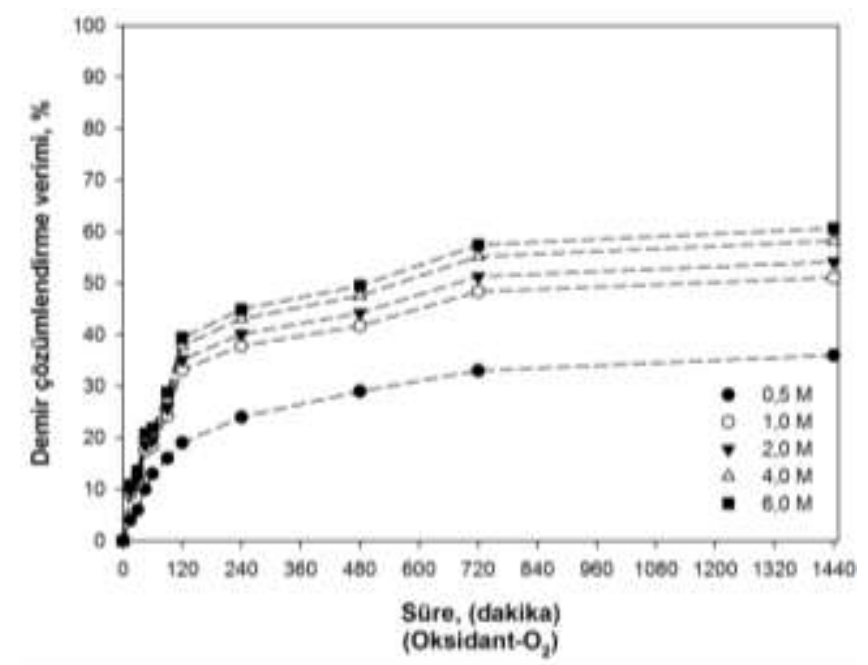

Şekil 4. Hidroklorik asit konsantrasyonun oksijen varlığında mat çözünme verimi üzerine etkisi (5 gr örnek, 200 $\mathrm{mL}$ çözücü, oda sıcaklığı, $50 \mathrm{mg}$ oksijen/dakika, 800 devir/dakika).

Şekil 4'de görüleceği üzere asit konsantrasyonun düşük olduğu durumda çözümlendirme üzerine pozitif bir etkiye sahip olduğu anlaşılmaktadır. Lakin, asit konsantrasyonun (4M'dan 6M'a çıkarılması durumunda) yüksek tutulmasının kayda değer bir artış sağlamadığı belirlenmiştir. Ayrıca çözümlendirme işlemlerinde kullanılması gereken asit miktarı 6 ve 7 nolu denklemlerden teorik olarak hesaplandığında piritin tamamının çözülmesi için gerek asit konsantrasyonu yaklaşık olarak $0,5 \mathrm{M}$ olarak tespit edilmiştir. Fakat çözümlendirme verimlerine ait grafikler göz önüne alındığında asit miktarının yaklaşık 8 katı kullanıldığında \%50'dan fazlasının çözündüğ̈̈ tespit edilmiştir.

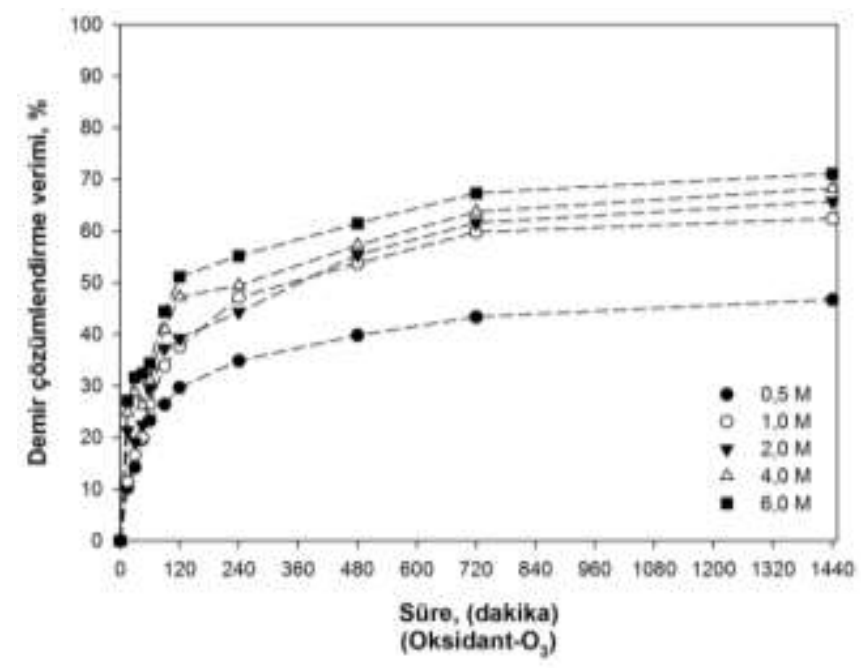

Şekil 5. Hidroklorik asit konsantrasyonun ozon varlığında mat çözünme verimi üzerine etkisi (5 gr örnek, 200 $\mathrm{mL}$ çözücü, oda sıcaklığı, $50 \mathrm{mg}$ ozon/dakika, 800 devir/dakika).

Ozonun oksidan olarak kullanılarak hidroklorik asidin konsantrasyonun incelendiği Şekil 5'den görüleceği üzere oksijen'de olduğu gibi benzer trend yakalanmış $6 \mathrm{M}$ asit varlığında verimin \%70'e ulaştı̆̆ 1 tespit edilmiştir [30]. Reaksiyonların gerçekleşme durumu oksidanların tipine bağlı olduğu kadar reaksiyon içerisinde var olan kükürdün ve çözeltiye geçen demir iyonlarının katalitik olarak tekrardan reaksiyonu yavaşlamaya yönelik davranış da bulunduğu düşünülmektedir. Bu düşünceyi Le chatelier prensibi desteklemektedir. Bir sonraki deney grubunda ozon oksidan olarak kullanılarak deneyler gerçekleştirilecektir. 


\subsection{Karıştırma hızının mat çözümlendirme verimi üzerine etkisi}

Karıştırma hızının incelendiği bu deney grubunda çözümlendirme reaktörüne oksidanın gaz yoluyla verilmesine ek olarak karıştırma hızıyla çözelti içerisinde çözünürlüğünün arttırılması ve bu artışa nasıl bir katkı sağlayacağını tam olarak anlaşılması amacıyla bir dizi deneyler gerçekleştirilmiştir.

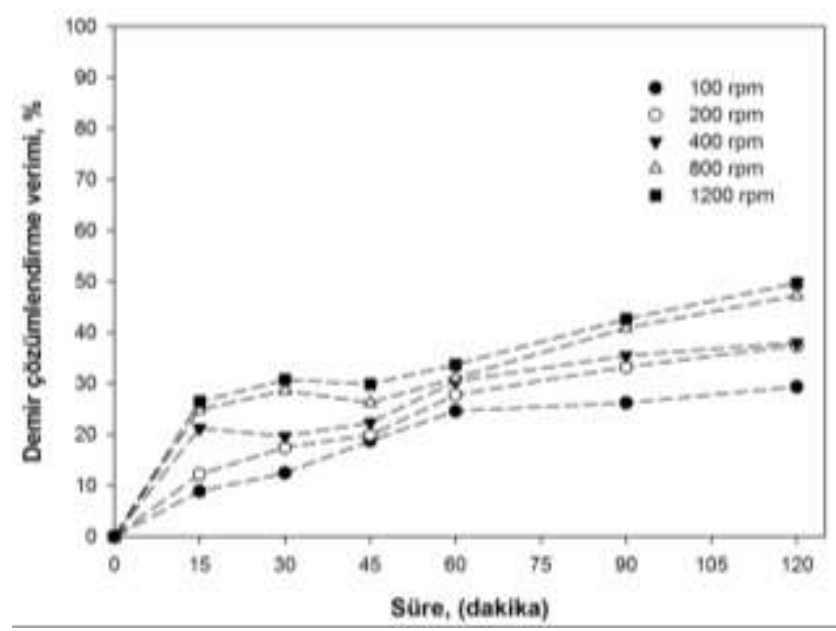

Şekil 6. Karıştırma hızının ozon varlığında mat çözünme verimi üzerine etkisi (5 gr örnek, 4 M HCl 200 mL, oda sicaklığı, $50 \mathrm{mg}$ ozon/dakika).

Karıştırma hızının pozitif etkisinin olacağı yönündeki tahminler Şekil 6'daki veriler ile örtüşmektedir. Grafik içerisindeki verilere bakıldığında zamanla doğrusal (lineer) bir artış gözlenmekte fakat karıştırma hızının 400 devir/dakika'dan 800 devir/dakika'ya çıkarılmasının ilk 60 dakikada çok etkili olmadığı tespit edilmiştir. Çözümlendirme deneylerinin oda sıcaklığında uzun sürelerde yapılacağı bir düzenekte karıştırma hızının pozitif etkisi daha çok gözlenmektedir. Fakat 1200 devir/dakika karıştırma hızının 800 devir/dakikaya göre pozitif bir etkiye sahip olmadığı aşikârdır. Ayrıca çok yüksek devirlerde yapılan karıştırma işlemlerinde sistemin sürdürülebilir çalışma verimine sahip olması da göz ardı edilmemesi gerekmektedir. Reaktörde herhangi bir sistemsel hata ve/veya çatlak oluşumu negatif etki oluşturabileceği öngörülmektedir.

\subsection{Sıcaklık ve sürenin çözümlendirme verimi üzerine etkileri}

Demir matının çözümlendirme verimlerinin yükseltilmesi için kimyasal reaksiyonlar için vazgeçilmez parametrelerden birisi olan sıcaklığının süre ile birlikte takip edildiği bu deney serisinde en uygun deney şartları bir önceki deneysel çalışmalar gözetilerek kullanılmıştır.

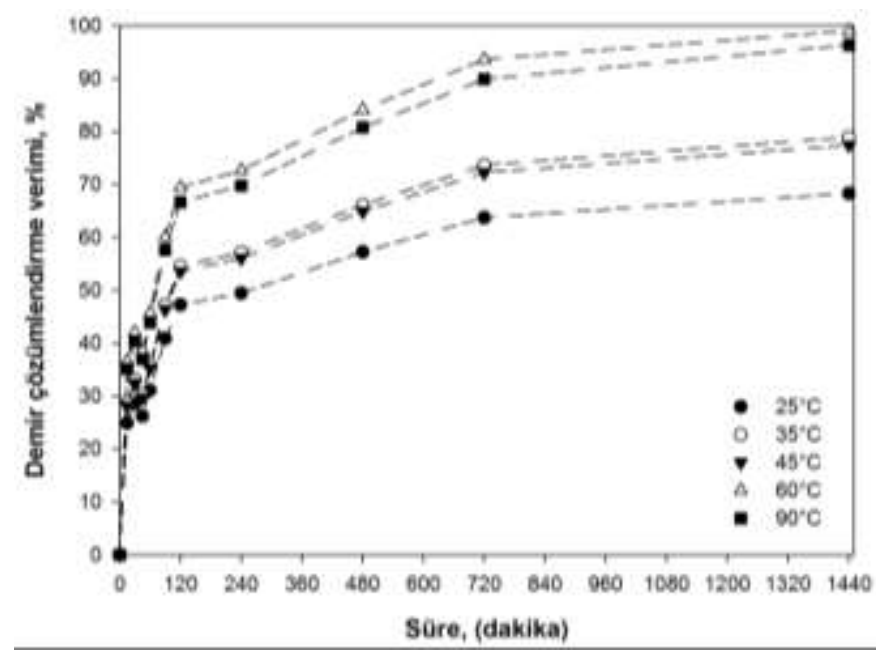

Şekil 7. Reaksiyon sıcaklığının ozon varlığında mat çözünme verimi üzerine etkisi (5 gr örnek, 4 M HCl 200 $\mathrm{mL}, 50 \mathrm{mg}$ ozon/dakika, 800 devir/dakika). 
Deney sıcaklığ 1 olarak $25^{\circ} \mathrm{C}^{\prime}$ den $90^{\circ} \mathrm{C}^{\prime}$ ye kadar belirlenen aralıklar kullanılarak demir çözümlendirme verimleri üzerine çalışmalar gerçekleştirilmiştir. Şekil 7'de görüldüğü üzere çözümlendirme verimi sıcaklıkla artış gösterdiğine dair veriler mevcuttur. Fakat oksidan olarak kullanılan ozonun artan sıcaklık ile sıvı sistem içerisinde çözünürlüğünün negatif yönlü etkilendiği literatürdeki çalışmalar ile sabittir. Örneğin; $45^{\circ} \mathrm{C}$ 'de elde edilen verilen $35^{\circ} \mathrm{C}$ 'de elde edilen verilerden çok azda olsa düşük kalmaktadır. Bu olumsuzluk ozonun artan sıcaklıktan negatif etkilendiğini göstermektedir. Benzer trendi $90^{\circ} \mathrm{C}$ ve $60^{\circ} \mathrm{C}$ sıcaklıkları içinde görebilmekteyiz [30]. $90^{\circ} \mathrm{C}$ 'deki verim değerleri $60^{\circ} \mathrm{C}$ 'nin altında kalmaktadır. Şekil $8^{\prime}$ 'de görüleceği üzere demir matının çözeltiye geçme veriminin 12 saat sonrasında kabul edilebilir değerlere ulaştı̆̆ (\%90 verim) tespit edilmiştir. Bu süreden sonra çözümlendirme verimi yükselemeye devam etmektedir.

\subsection{Liç işlemi sonrası elde edilen kalıntıya ait sem görüntüsü}

Liç işlemleri sonrası elde edilen atığa ait toz iletkenlik sağlamak amacıyla altın kaplama yapılıp yüksek vakumlu taramalı elektron mikroskobu ile görüntüleme işlemleri yapılmış ve elde edilen görüntüler Şekil 8 ve 9'de verilmiştir. Görüntüleme sırasında yüzey analizleri EDS ünitesi ile yapılmış ve görüntünün alındığı bölgede tespit edilen yapılar belirlenmiştir. Şekil 13'de sülfürlü PGM'lerin genel SEM görüntüsü verilmiştir. Görüldüğü üzere PGM kalıntısı kısmen polimerleşme görüntüsü içermektedir. Görüntü içerisinde yer alan her bir bölge birbirinin aynısıdır. Bu görüntüye ait bölgeler içerisinden herhangi bir alan seçilerek SEM görüntüsü büyütüldüğünde kükürt den dolayı yapının polimerize olmuş gibi bir hali mevcuttur.
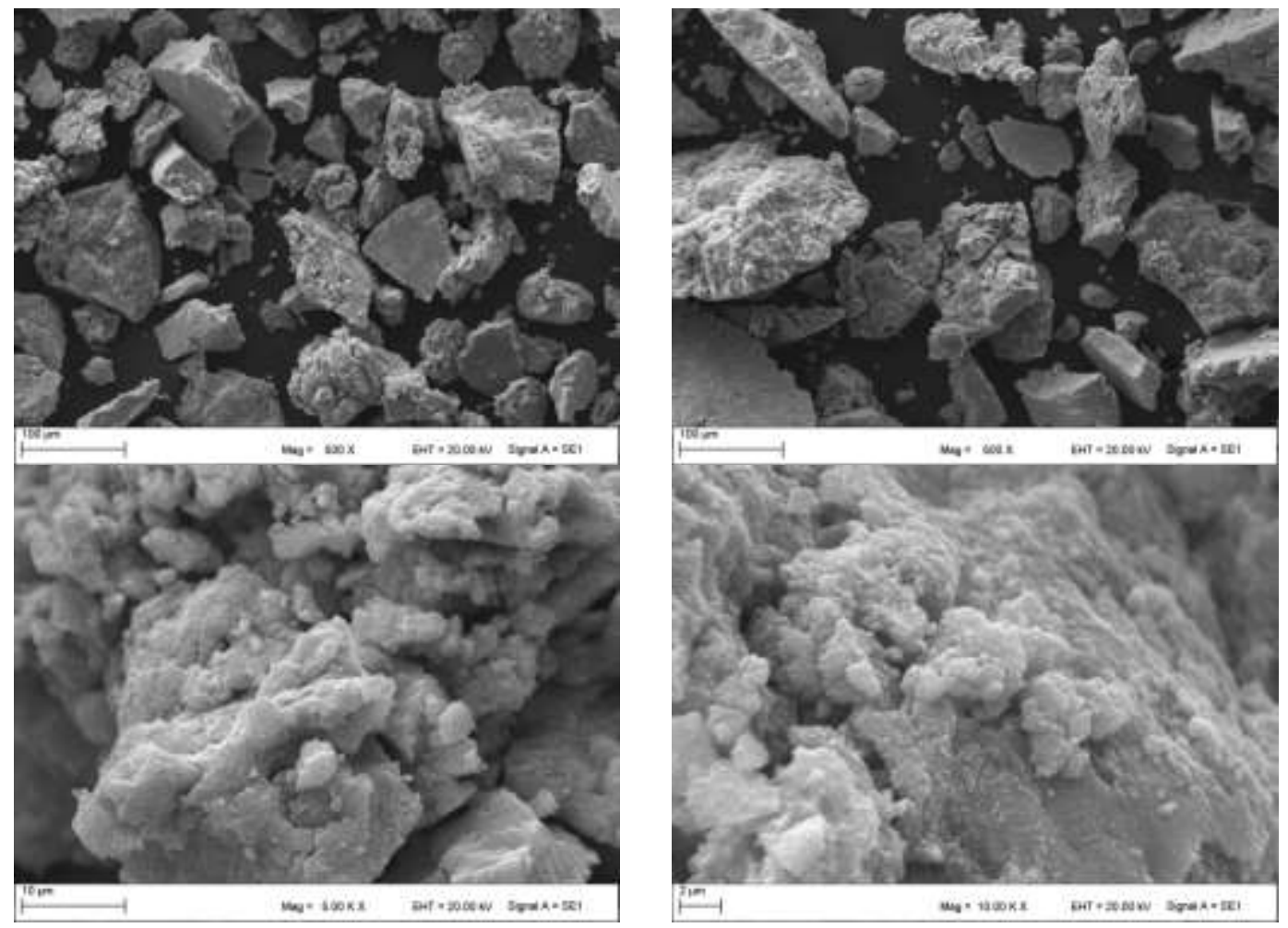

Şekil 8. Liç işlemi sonrası arta kalan PGM kalıntısına ait SEM görüntüsü. 


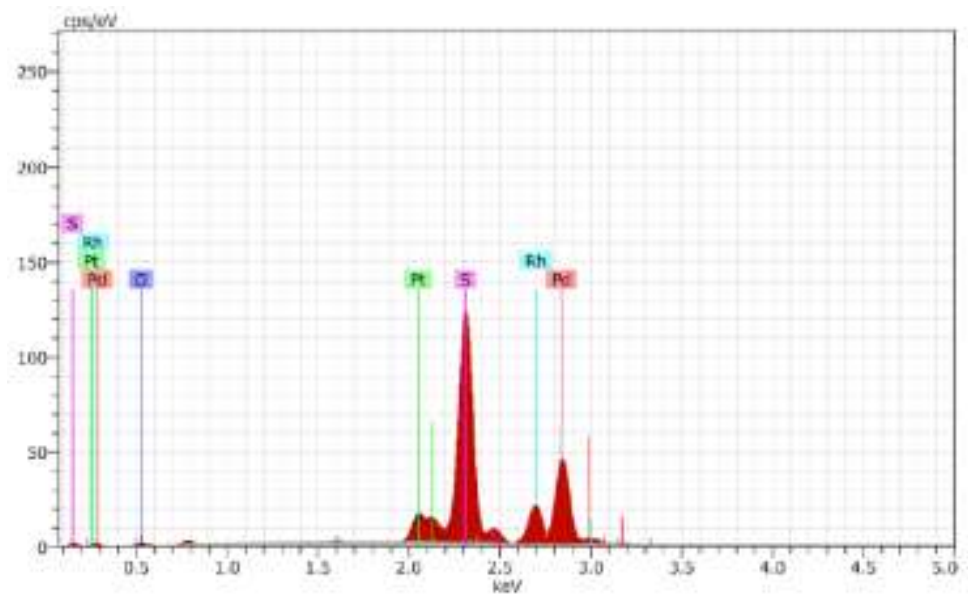

Şekil 9. Matın çözünmesi sonrası arta kalan PGM kalıntısına ait EDS analizi.

10K büyütme sonrası EDS analizi yapılarak bölgenin içerisinde bulunan Pt-Pd-Rh-S bileşiklerinin olduğu tespit edilmiştir. Mat içerisinde PGM'lerin konsantrasyonlarına göre dengeli bir dağ 11 lı içeren EDS grafiği Pd değerinin en yüksek oluşundan ötürü en yüksek pik elde edilmiştir. Pt ve $\mathrm{Rh}$ değerleri için elde edilen grafik alanı uygundur. PGM'lerin sülfürlü bileşiklerinin çözünürlük sabitlerinin çok düşük olmasından ( $\mathrm{PtS}$ için $\mathrm{Kçç}=8 \times 10^{-73}$; $\mathrm{PdS}$ için $\mathrm{Kçç}=2 \times 10^{-58}$ ve $\mathrm{Rh}_{2} \mathrm{~S}_{3}$ için $\mathrm{Kçç}=$ $10^{-51}$ ) dolayı matın hidroklorik asidi varlığında çözünmesi sırasında ihmal edilebilecek miktarda (ppb düzeylerinde) çözündüğü yapılan analizler ve ağırlık tartımları ile kontrol edilmiştir [30]. Elde edilen bu bulgu analitik kimya ders kitaplarında katyonlarının tespiti ve birbirlerinden ayrıştırılması konusu başlı̆̆ında PGM'lerin $\mathrm{HCl}$ ile temasında bir çözünme olmayacağı belirtilmektedir.

\section{Sonuç ve Öneriler}

Bu araştırma makalesinde katalitik dönüştürücüler içerisinde bulunan PGM'lerin yüksek sıcaklıkta kat1katı ekstraksiyon yöntemiyle katalitik dönüştürücülerden ayrılması sonucu elde edilen demir matının oksidatif şartlar altında çözünme verimine etki eden parametreler incelenmiştir. Deneylerin gerçekleştirildiği basamaklarda hammadde XRD ve çözünmeden geri kalan malzeme SEM-EDS tekniği ile karakterize edilmiştir. Çözümlendirme parametreleri birbirleriyle ilişkili olarak takip edilmiş deneyler sonucunda elde edilen verilen doğrultusunda 5 gr demir matının $4 \mathrm{M} \mathrm{HCl} 200 \mathrm{~mL}$ ile $50 \mathrm{mg}$ $\mathrm{O}_{3} /$ dakika ve 800 devir/dakika reaksiyon şartlarında 12 saat süre sonunda $60^{\circ} \mathrm{C}$ reaksiyon sicaklığında \%95 üzerinde verim elde edilebilmiştir. Reaksiyonun yavaşladığ1 ve/veya reaksiyon hızının istenilen düzeylerin altında kalması durumunda, yeni taze hazırlanmış çözelti ile reaksiyon kaldığı yerden devam ettirilebileceği önerilmektedir.

Deneyler sonucu elde edilen veriler doğrultusunda PGM'lerin geri kazanımı konusunda geliştirilen katı-katı ekstraksiyon yönteminden elde edilen demir matının çözeltiye alınma şartlarının incelenmesi bu alanda yapılabilecek mat çalışmalarına katkı sağlayacaktır. Bu veriler ile endüstriyel katı özellikle katalitik dönüştürücülerin önemli bir hammadde kaynağı olduğu düşünülecek olursa bu atıklardan elde edilen demir matının çözeltiye alınması için yeni bir bakış açısı ortaya konulması çalışılmıştır.

\section{Teșekkür}

Bu çalışma; Türkiye Bilimsel ve Teknolojik Araştırma Kurumu (TÜBİTAK) tarafindan 217M284 numaralı proje kapsamında desteklenmiştir. Makalenin bilimsel olarak gelişimine katkı sağlayan hakemlere ve derginin bölüm editörüne teşekkür ederiz.

\section{Yazarların Katkısı}

Yazarlar eşit oranda katkı sağlamışlardır. 


\section{Çıkar Çatışması Beyanı}

Yazarlar arasında herhangi bir çıkar çatışması bulunmamaktadır.

\section{Araştırma ve Yayın Etiği Beyanı}

Yapılan çalışmada araştırma ve yayın etiğine uyulmuştur.

\section{Kaynaklar}

[1] Dong H., Zhao J., Chen J., Wu Y., Li B. 2015. Recovery of platinum group metals from spent catalysts: a review. International Journal of Mineral Processing, 145 108-113.

[2] Crundwell F.K., Moats M., Ramachandran V. 2011. Extractive metallurgy of nickel, cobalt and platinum group metals. Elsevier, 334-360.

[3] Kolliopoulos G., Balomenos E., Giannopoulou I., Yakoumis I., Panias D. 2014. Behavior of platinum group metals during their pyrometallurgical recovery from spent automotive catalysts. Open Access Library Journal, 1 (5): 1-5.

[4] Morcali M.H., Akman S., Yucel O. 2015. Determination of the Optimum NiS Fire Assay Parameters for Pt, $\mathrm{Pd}$, and $\mathrm{Rh}$ in Automotive Exhaust Catalytic Converters. Chemical Engineering Communications, 202 (9): 1145-1154.

[5] Peng Z., Li Z., Lin X., Tang H., Ye L., Ma Y., Rao M., Zhang Y., Li G., Jiang T. 2017. Pyrometallurgical Recovery of Platinum Group Metals from Spent Catalysts. JOM, 69 (9): 1553 1562.

[6] Jung V. 1991. Automotive exhaust catalysts: PGM usage and recovery. EMC '91: Non-Ferrous Metallurgy-Present and Future. Dordrecht, Springer, Netherlands, 231-239.

[7] Yamada K., Ogino M., Ezawa N., Inoue H. 2010. Method and apparatus for recovering platinum group elements. US patent 7,815,706.

[8] Hoffmann J.E. 1988. Recovery of platinum-group metals from gabbroic rocks metals from auto catalysts. JOM, 40 (6): 40-44.

[9] Ezawa N., Inoue H., Takada S., Masuda H. 1993. Process of recovering platinum group metal. US patent 5,252,305.

[10] Van Schalkwyk R.F., Eksteen J.J., Akdogan G. 2013. Leaching of Ni-Cu-Fe-S converter matte at varying iron endpoints; mineralogical changes and behaviour of $\mathrm{Ir}, \mathrm{Rh}$ and $\mathrm{Ru}$. Hydrometallurgy, 136: 36-45.

[11] Ivanović S.Z., Gorgievski M.D., Božić D.S., Trujuć V.K., Mišić L.D. 2011. Removal of platinum group metals (PGMs) from the spent automobile catalyst by the pyrometallurgical process. 15th International Research/Expert Conference, TMT 2011. Prague, Czech Republic, 701-710.

[12] Fornalczyk A., Saternus M. 2009. Removal of platinum group metals from the used auto catalytic converter. Metalurgija, 48 (2): 133-136.

[13] Hagelüken C. 2006. Recycling of electronic scrap at Umicore precious metals refining. Acta Metallurgica Slovaca, 12: 111-120.

[14] Kim B.-S., Lee J.-C., Jeong J., Yang D.-H., Shin D., Lee K.-I. 2013. A Novel Process for Extracting Precious Metals from Spent Mobile Phone PCBs and Automobile Catalysts. Materials Transactions, 54 (6): 1045-1048.

[15] Kim B.-S., Lee J.-C., Seo S.-P., Park Y.-K., Sohn H.Y. 2004. A process for extracting precious metals from spent printed circuit boards and automobile catalysts. JOM, 56 (12): 55-58.

[16] Keyworth B. 1982. The role of pyrometallurgy in the recovery of precious metals from secondary materials. Precious Metals 1982, Sixth International Precious Metals Institute Conference, California, USA, June 7-11.

[17] Burkhard R., Hoffelner W., Eschenbach R.C. 1994. Recycling of metals from waste with thermal plasma. Resources, Conservation and Recycling, 10 (1): 11-16.

[18] Boulos M.I., Fauchais P., Pfender E. 2013. Thermal Plasmas: Fundamentals and Applications. Springer US. 
[19] Fornalczyk A., Saternus M. 2013. Vapour treatment method against other pyro-and hydrometallurgical processes applied to recover platinum from used auto catalytic converters. Acta Metallurgica Sinica, 26 (3): 247-256.

[20] Kayanuma Y., Okabe T.H., Maeda M. 2004. Metal vapor treatment for enhancing the dissolution of platinum group metals from automotive catalyst scrap. Metallurgical and Materials Transactions B, 35 (5): 817-824.

[21] Han K.N., Kim P.N.-s. 2006. Recovery of platinum group metals. U.S. Patent 7,067,090.

[22] Yamada K., Ogino M., Ezawa N., Inoue H. 2010. Method and apparatus for recovering platinum group elements. US patent 7,815,706.

[23] Shibuya E.K., Sarkis J.E.S., Enzweiler J., Jorge A.P.S., Figueiredo A.M.G. 1998. Determination of platinum group elements and gold in geological materials using an ultraviolet laser ablation high-resolution inductively coupled plasma mass spectrometric technique. Journal of Analytical Atomic Spectrometry, 13 (9): 941-944.

[24] Juvonen M., Bartha A., Lakomaa T.M., Soikkeli L.A., Bertalan E., Kallio E.I., Ballok M. 2004. Comparison of Recoveries by Lead Fire Assay and Nickel Sulfide Fire Assay in the Determination of Gold/Platinum/Palladium and Rhenium in Sulfide Ore Samples. Geostandards and Geoanalytical research, 28 (1): 123-130.

[25] Peng Z., Li Z., Lin X., Tang H., Ye L., Ma Y., Rao M., Zhang Y., Li G., Jiang T. 2017. Pyrometallurgical Recovery of Platinum Group Metals from Spent Catalysts. JOM, 69 (9): 1553 1562.

[26] Van Schalkwyk R.F., Eksteen J.J., Petersen J., Thyse E.L., Akdogan G. 2011. An experimental evaluation of the leaching kinetics of PGM-containing Ni-Cu-Fe-S Peirce Smith converter matte, under atmospheric leach conditions. Minerals Engineering, 24 (6): 524-534.

[27] Jeffery G.H., Bassett J., Mendham J., Denney R.C. 1991. Vogel's Textbook of Quantitative Chemical Analysis. Fifth Edition. Longman Scientific \& Technical, Great Britain 314-327.

[28] Hwang C.C., Streeter R.C., Young R.K., Shah Y.T. 1987. Kinetics of the ozonation of pyrite in aqueous suspension. Fuel, 66 (11): 1574-1578.

[29] Rodríguez-Rodríguez C., Nava-Alonso F., Uribe-Salas A. 2018. Pyrite oxidation with ozone: stoichiometry and kinetics. Canadian Metallurgical Quarterly, 57 (3): 294-303.

[30] Viñals J., Juan E., Ruiz M., Ferrando E., Cruells M., Roca A., Casado J. 2006. Leaching of gold and palladium with aqueous ozone in dilute chloride media. Hydrometallurgy, 81 (2): 142-151. 